\title{
Effects of progestin-only contraceptives on the phenotype and function of female reproductive tract CD4+ and CD8+ T cells
}

\author{
Uma Shanmugasundaram", JW Critchfield', J Pannell ${ }^{2}$, J Perry² ${ }^{2}$ WC Greene ${ }^{2,3}$, L Giudice $^{2}$, K Smith-McCune ${ }^{2}$, \\ RM Greenblatt ${ }^{2}$, BL Shacklett ${ }^{1}$
}

From 2nd International Science Symposium on HIV and Infectious Diseases (HIV SCIENCE 2014)

Chennai, India. 30 January - 1 February 2014

\section{Background}

Use of progestin-only contraceptives may enhance the susceptibility of the female reproductive tract (FRT) to HIV infection. We assessed the effects of progestin-only contraceptives, including Depo-Provera (DMPA), and the levonorgestrel intra-uterine system (LNG iUS) on endometrial and endocervical mucosa of premenopausal women.

\section{Methods}

Participants using either DMPA $(\mathrm{n}=15)$ or the LNG iUS $(n=19)$ for at least 3 months and women using no hormonal contraceptives $(n=24)$ were recruited. Endocervical curettage, endocervical cytobrush, and endometrial biopsy were obtained from all women. Expression of T cell activation markers, memory/effector differentiation markers and HIV co receptors were assessed by multiparameter flow cytometry. CD4+ and CD8+ T cells producing CD107a, IL-10, IL-2, IFN $\gamma$, MIP1 $\beta$ and IL-17 were measured after stimulation with PMA/ionomycin or staphylococcal enterotoxin B (SEB).

\section{Results}

Endometrial CD4+ and CD8+ T cells and endocervical CD8+ T cells were highly activated in women using LNG iUS as compared to controls. Compared to DMPA, LNG iUS resulted in increased activation of endocervical curettage CD4+ T cells. CXCR4+CCR5+CD4+ T cells in the endometrium and curettage were increased in women using LNG iUS as compared to controls. The percentage of endocervical central memory CD4+ and CD8+ T cells were decreased in LNG iUS recipients. Following SEB stimulation, endometrial $\mathrm{CD} 4+\mathrm{T}$ cells responded with production of IL-10, IL-2 and IL-17. CD8+ T cells produced elevated percentages of IL-10 in women using LNG iUS compared to control women.

\section{Conclusion}

LNG iUS and DMPA affected endocervical and endometrial $\mathrm{T}$ cell phenotype and responsiveness to polyclonal stimulation. Further studies are warranted to clarify the effects of contraceptive products on upper FRT immune cells and HIV susceptibility.

\section{Authors' details}

${ }^{1}$ University of California, Davis, USA. ${ }^{2}$ University of California, San Francisco, USA. ${ }^{3}$ Gladstone Institute of Virology and Immunology, San Francisco, CA, USA.

Published: 27 May 2014

\section{doi:10.1186/1471-2334-14-S3-O21}

Cite this article as: Shanmugasundaram et al:: Effects of progestin-only contraceptives on the phenotype and function of female reproductive tract CD4+ and CD8+ T cells. BMC Infectious Diseases 2014 14(Suppl 3): 021.

* Correspondence: umashanmugasundaram@ucdavis.edu

${ }^{1}$ University of California, Davis, USA

Full list of author information is available at the end of the article 